\title{
Development of Educational Playing Cards as Learning Media for Introducing Figures and Works of Fine Art to High School Students
}

\author{
Rony Siswo Setiaji*, Zulfi Hendri, Uswahtun Hanisah, Aran \\ Handoko' Vidia Riadianti Putri
}

Faculty of Languages and Arts, Yogyakarta State University, Yogyakarta, Indonesia

*Corresponding author. Email: ronysiswo@uny.ac.id

Author.Email: zulfi hendri@uny.ac.id

\begin{abstract}
This is a research and development study on the development of educational playing cards as the learning media for introducing figures and works of fine art to Year 11 high school students in Yogyakarta. This study aims to 1) describe the process of developing the educational playing cards as learning media, and 2) show the quality of the learning media based on the quality of the materials and media. This study used the descriptive statistical data analysis technique. The research subjects were Year 11 high school students in Yogyakarta. The data collection techniques involved interviews, observation, documentation, and survey. The research and development used the ADDIE model consisting of analysis, design, development, implementation, and evaluation. Needs analysis on the students' competencies were done, followed by selecting elements of design of the educational playing cards such as the images, sketches, and layout. The next step was to transform the design into the physical product, followed by implementation on the product. The last stage was done to improve the flaws in the quality development of the product. This study is expected to motivate students in learning activities and help educators to deliver the learning materials.
\end{abstract}

Keywords: Learning media, Educational playing cards, Figures, Works of fine art

\section{INTRODUCTION}

The teaching and learning activities in school can work optimally using learning media. Without learning media, often learning activities are done conventionally by educators through verbal delivery or the lecture method. Verbal delivery may result in misperceptions and reduce students' interest in receiving and understanding the learning materials [9].

Learning media may facilitate educators in delivering information or learning materials and allow students to receive said information or learning materials. Learning media facilitate the educators and students so that students can understand the materials in an effective and efficient manner [4]. Therefore, educactors are expected to use creative and attractive learning media to motivate students and achieve the learning goals. This also applies in the Arts and Culture subjects in Year 11 in high school in the knowledge aspect competency, which requires the use of learning media to help students master and understand the materials conveyed by educators.

The Arts and Culture subject of Year 11 students in high school in the basic competency 3.4 refers to the learning activity of observing and learning prominent artists and their works. Based on the preliminary study, the following information is obtained. 1) the educator or teacher delivered the learning material on the introduction of figures and works of fine art through lectures and presentations; 2) the teacher did not use creative or attractive learning media; 3 ) the teacher only explained parts of the material on figures and works of fine art, so that students did not receive the complete information; 4) students were bored and unmotivated by teacher's explanation and presentation, and as a result, they did not absorb the learning material on figures and works of fine art; and 5) about $67 \%$ of students still were not familiar with figures and works of fine art, although the material had been taught by teachers in the class. Therefore, there needs to be creative and attractive learning media to help students and teachers convey and 
receive information on prominent artists and their works.

\section{LITERATURE REVIEW}

\subsection{Fine Art Education in High School}

Education is the effort done by each individual to develop their respective competencies. One of the competencies which must be developed by individuals is art. Through artistic endeavors, one may develop and improve their intelligence, including their intellectual intelligence, imagination, creativity, emotional intelligence, social intelligence, and aesthetics. This is in line with a statement by Irawan [3] on how art education develops and sharpens all human potentials, such as the ability for expressing, creating, and appreciating so that they can exist and create life that is in harmony, humanist, and upholds the cultural values.

Arts and culture learning in high school particularly involves four competencies that must be possessed by students, namely the spiritual attitude, the social attitude, knowledge, and skills. This study focuses on the development of the knowledge competency on the Fine art subject for Year 11, especially in the basic competency 3.4 on analysing concepts, procedures, functions, figures, and aesthetic values in works of fine art with learning materials focusing on introducing figures and works of fine art.

\subsection{Learning Media}

Media is a means to facilitate in delivering information from a source to the receiver. Learning media refer to the tools used as the media to convey the learning material content which may include books, tape recorders, cassette tapes, videos, films, slides, photographs, images, graphics, etc. [1]. Learning media may help educators in delivering information and students in receiving said information to achieve the learning goals. Learning media has a central position in the learning system, as the lack of learning media may result in less-than-optimal teaching learning activities.

Educators may use various types of learning media that are adjusted and with the students' needs and characteristics, as well as the learning materials.based on the advancement of technology, learning media can be grouped into four types, namely a) print media convey information through texts, photographs, images, and cards; b) audio-visual media convey information through sound recording and moving pictures as in films, videos, and projectors; c) computer-based media convey information through microprocessor with digital computer technology; d) mixed-media are the combination of several types of media, such as multimedia. Educational card game learning media or educational playing cards have a physical print form and illustrations [1].
Learning media have various beneficial functions for students and educators in the teaching learning activity, namely: a) students may learn about the past; b) students can see unattainable object due to distance, danger, or restriction; c) students gain visualization on something that may either be too large or too small; d) it is easier to compare things; e) it can be used to summarize something extensive; and f) students can learn based on their abilities and interests [2].

Learning media offers benefits to the users. First, they facilitate the needs of students. Secondly, they may improve the learning quality as the lesson content may be adjusted by the educators. Third, the use of learning media can make learning more exciting, enjoyable, and interesting. Lastly, the class becomes more interactive and communicative [6]. These benefits may improve with the appropriate principles, namely selecting the materials or media according to needs, introducing materials to students by referring to the previous materials and showing the relation with the learning goals, receiving feedback from students, and evaluating the learning media [5].

\subsection{Educational Playing Cards}

Educational playing cards are illustrated print media containing certain information aimed to be played as a game. As learning media, educational playing cards are creative and attractive to be applied in the teaching learning activities to improve the motivation of students. Educational card game as learning media has the benefit as it is one of the effective education tools to improve the academic performance of students, improve their ability in analysis, and preserve knowledge longer [7].

Educational playing cards as visual learning media have both advantages and disadvantages. The advantages are as follows: a) visual media help improve the effectiveness of learning objective achievement; b) visual media make the learning process run better; c) visual media can improve understanding and strengthen memory with attractive appearance; d) visual media can be used over and over; e) visual media help students to think sharply and specifically; f) visual media accommodates the limitation of experience, improving interaction and communication, and motivate students' interest and desire. The disadvantages of educational playing cards as learning media are as follows: a) visual media in print format cannot incorporate audio, so that the material cannot include more details; b) visual media sometimes are slow and less practical; c) visual media in print format requires a relatively high production cost; and d) visual media require careful observation [9].

\section{RESEARCH METHOD}

This study is a research and development study on the development of educational playing cards as learning media for introducing figures and works of fin arts for high school students. Research and development 
aims to generate a product based on the needs analysis and ensure the that product has a good quality and benefit the society [8]. The learning activity of fine art for Year 11 students in high school, especially the material of introducing figures and works of fine art require learning media in the form of educational illustrated playing cards in order to make the teaching learning activity more exciting and motivate students in learning the figures and works of fine art.

The research model used the ADDIE development model. The analysis stage includes needs analysis. In this study, this was done on the skill or competency required by students. The next stage is the design stage, involving selecting the works of art, the art movement, the prominent figures, the making of sketches of the cards, as well as making the layout and the rule of the game. The development stage is where the conceptual framework is transformed into a product that is ready to be used. The implementation stage refers to the stage where the product is applied, followed by the evaluation stage consisting of formative and summative evaluations. In this study, formative evaluation each the product was evaluated in each development phase regarding the quality of content or material and media in the product.

\subsection{Data Collection Technique}

The data collection techniques in this study include observation, interviews, documentation, and a survey or questionnaires. The observation was done in a preliminary study to identify the learning media on introducing the figures and works in fine art. Preliminary study was also done to examine how the learning process takes place in the class in the material of introducing the figures and works of fine art. Interviews were done to examine how students learn about the figures and works of fine art. Documentation was done by collecting data on the learning instruments involving syllabus and lesson plans, in addition to data on students who participated in the product trial. The survey or questionnaires in the study aimed to determine the quality of the learning media according to material and media experts.

\section{DISCUSSION}

\subsection{The Analysis Stage}

The analysis stages involve needs analysis and work analysis. The result of needs analysis is that in the Arts \& Culture subject for Year 11, the outcome of basic competency 3.4 demands students to observe and identify figures and works of fine art. The learning indicators include the ability to understand and explain various art movements, the ability to identify figures in fine art, and the ability to observe examples of works of fine art.
The work analysis involves interviews and observation. Based on the interview, about $67 \%$ of the students were not familiar with figures and works of art, even though the teacher had explained the lesson during class. Meanwhile, the observation found the following. a) The educator or teacher delivered the material of introducing figures and works of fine art by presentations and lectures b) The teacher did not use interesting and creative learning media. c) The teacher only explained some figures and works of art, hence students received incomplete material. d) Students were bored and not motivated to listen to teacher's explanations and presentations, hence they did not absorb the learning material of introducing figures and works of fine art appropriately.

\subsection{The Design Stage}

In this stage, the researcher begins designing sketches for the product of educational playing cards for introducing figures and works of fine art. The result of the initial design shows the front and back sides of the card. The front side consists of the art movement or style of the painting, the title of the piece, the image of the painting, and the name of the painter. There are forty cards with ten styles of art movement, each with four main figures and works involving romanticism, realism, abstract, impressionism, cubism, dadaism, expressionism, pop art, and surrealism. Figure 1 below shows the initial sketch design of educational playing cards for introducing figures and works of fine art.

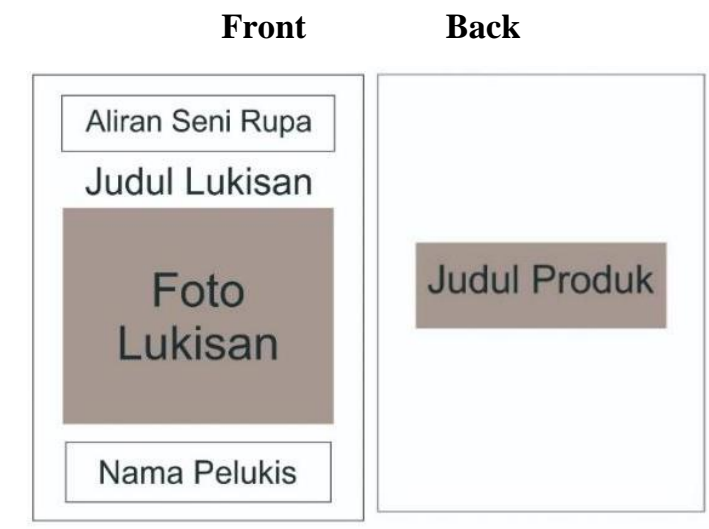

Figure 1. Initial sketch

\subsection{The Development Stage}

The development stage is the stage of realizing the product. While the design stage has finalized the design of the initial sketch of the product, in the development stage, the initial sketch is turned into the product design. Figure 2 below shows the result of the Draft I development stage of educational playing cards for introducing figures and works of fine art. 


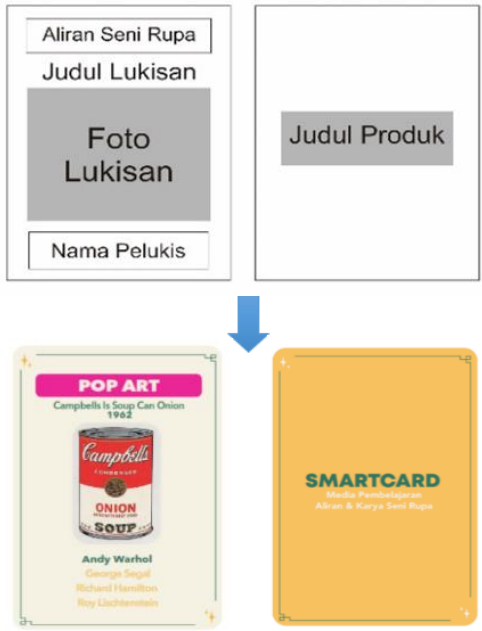

Figure 2. Development of sketch into the Draft I product design

\subsection{Implementation}

In the implementation stage, the suggestions from media and material experts are implemented to generate the final product. The material experts' suggestion on the product was to provide more information on various styles or art movements, the year produced, and the origin country of the figures. Meanwhile, the media experts suggested that the font colors be clarified to have more contrast. Figure 3 below depicts the final product of educational playing cards for introducing figures and works of fine art.

\section{Before}
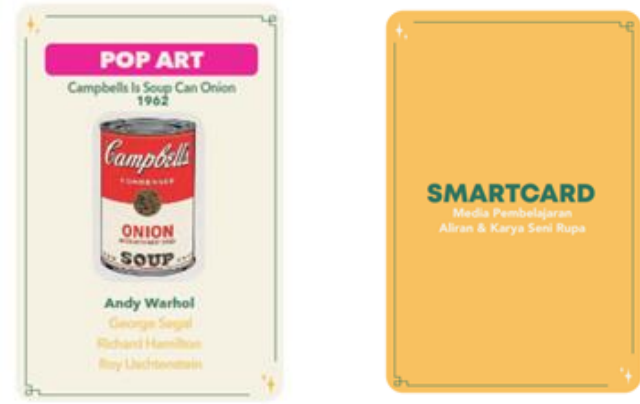

After
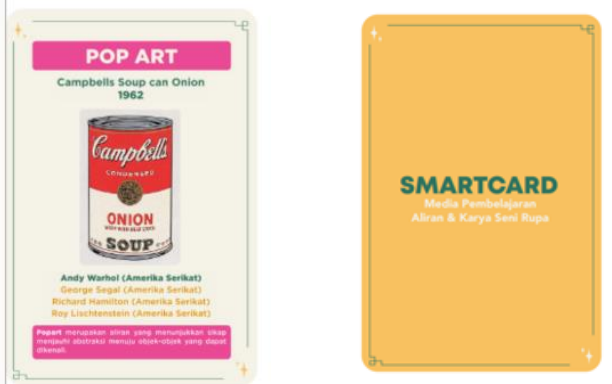

Figure 3. Final product evaluation
Figure 4 below shows some examples of the final product of playing cards for introducing the figures and works of fine art.

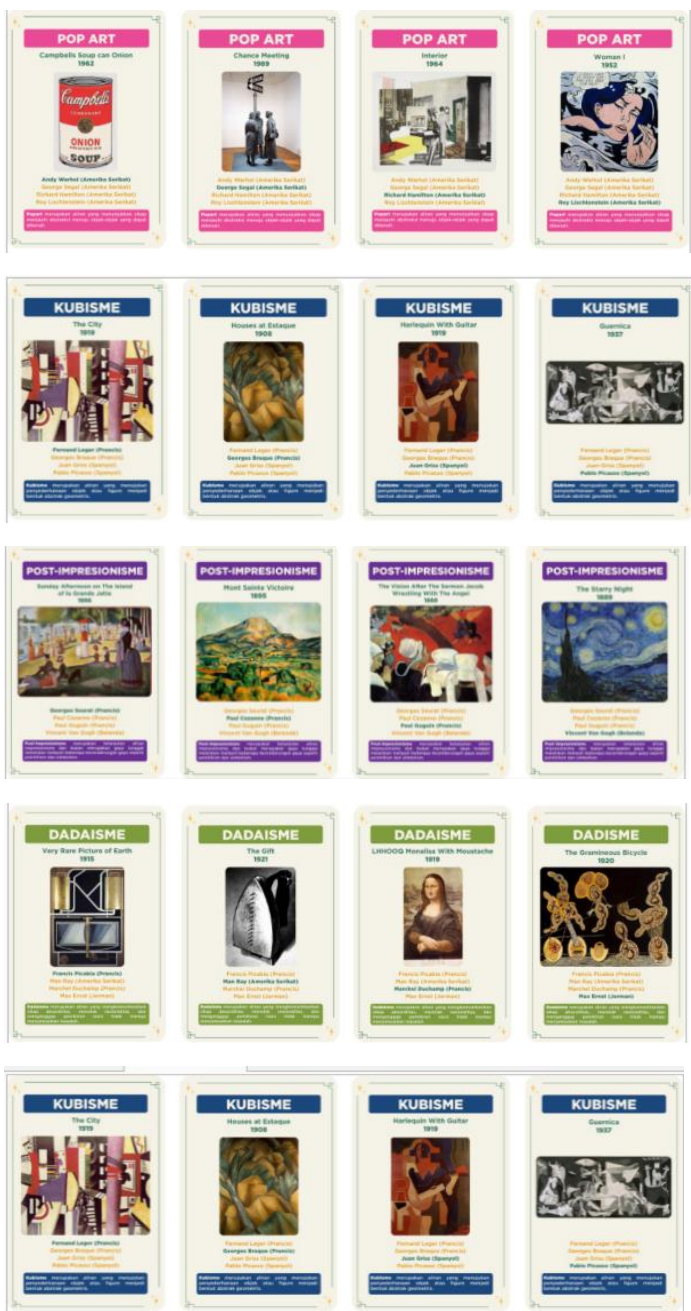

Figure 4. Some examples of the final product

\subsection{The Evaluation Stage}

In this stage, product assessment from the material and media experts were obtained to ensure the quality of the product and that it was feasible for use. The Draft 1 product scored a total of 3.3 in B category (Good) from the material experts. The suggestion was to provide more information on the art movements, the year produced, and the origin country of the figures. Draft II scored higher with 4.4 in the SB category (Excellent).

Meanwhile the product scored a total of 3.5 in the B category (Good) from the media experts in Draft I, with a suggestion to clarify the font colors to have more contrast. Draft II scored 4.6 in the SB category (Excellent).

\section{CONCLUSION}

The educational playing cards learning media for introducing figures and works in fine art to high school 
students have Excellent quality based on the final product assessment by material and media experts with scores of 4.4 and 4.6 , respectively.

\section{REFERENCES}

[1] Arsyad, Azhar. Media Pembelajaran [Learning Media], Rajawali Pers, 2016.

[2] Daryanto. Media Pembelajaran Peranannya Sangat Penting Dalam Mencapai Tujuan Pembelajaran [The Role of Learning Media Is Very Important in Achieving Learning Objectives]. Gaya Media, 2013.

[3] Irawan, Deddy. Paradigma Pendidikan Seni [The Paradigm of Arts Education]. Thafa Media Offset, 2017.

[4] Musfiqon. Pengembangan Media dan Sumber Media Pembelajaran [Media Development and Learning Media Resources]. PT Prestasi Pustakarya, 2012.

[5] Naz, Ahsan Akhtar \& Rafaqat Ali Akba. Use of Media for Effective Instruction its Importance: Some Consideration. Journal of Elementary Education, vol. 18, no. 1-2, 2008, pp. 35-40

[6] Onasanya, S. A. Selection and utilization of instructional media for effective practice teaching. Institute journal of studies in education, vol. 2, no.1, 2004, pp. 127-133.

[7] Rajashekar, R.K. \& Anjana, Bellad. Effectiveness of educational playing cards as a supplementary educational tool in academic performance. Indian Journal of Clinical Anatomy and Physiology, vol.3, no. 1, 2016, pp. 4-7. URL: ijcap.org/articledetails/1421

[8] Sugiyono. Metode Penelitian Kuantitatif, Kualitatif dan $R \& D$ [Quantitative Research Methods, Qualitative Research Methods, and R \& D]. Alfabeta, 2009.

[9] Wati, Ega Rima. Ragam Media Pembelajaran [Varieties of Learning Media]. Kata Pena, 2016. 